\title{
Herbert Bolton, D.Sc., F.G.S., F.Z.S.
}

Herbert Bolton, Director of the Bristol Museum and Art Gallery from 1898 to his retirement in 1930 , died on January I8, I936, at Reading, where he had resided since I93I. Born in 1863 in Bacup, Lancashire, he early displayed an enthusiasm for natural history, for indulgence in which full opportunity was provided when he proceeded to the Royal College of Science, South Kensington, in I886. Returning north, he attended the old Owens College, Manchester, and in I 890 was appointed to an Assistant Keepership in the Manchester Museum. In 1898 he succeeded to the Curatorship of the Bristol Museum, and was promoted to be the first Director of the Museum and Art Gallery in I9I I, a position which he held with distinction until his retirement on age limitations.

Throughout his career Bolton combined in a most successful manner his professional obligations to the Museum with his enthusiasm for research. From a small institution, with no outstanding features, he rapidly advanced the Bristol Museum to a leading position among provincial museums, and was one of the first to introduce into England the natural grouping system for exhibits. He was honoured by a seat on the Advisory Board of the Victoria and Albert Museum, Kensington, and was invited to give evidence before the Royal Commission on National Museums. He was an ardent member of the Museums Association, and occupied the presidential chair of the Association in 1925.

$H$ is research activities centred round the stratigraphy and palæontology of the Coal Measures, beginning with those in Lancashire and later transferred to the formations around Bristol. Both series of studies have a recognised value in practical mining operations. The small and special group of Carboniferous insects ultimately received his chief attention, his description of the giant dragon-fly, Boltonites [Meganeura] radstockensis, Bolton, being particularly noteworthy. Finally, the Palæontological Society published in 1921-22 a comprehensive monograph by him which will for long remain the standard work on Coal Measure insects.

Dr Bolton was for many years associated with the University of Bristol as Reader in Palæontology, and as a member of the Court of the University. As a recognition of his palæontological researches the honorary degree of D.Sc. was conferred upon him by the University in 1922, and in the same year he was given the award of the Murchison 
Fund by the Geological Society of London. He was elected a Fellow of the Royal Society of Edinburgh as early as 1894, of the Zoological Society of London in 1905, and a member of the Geological Society in 1906.

Throughout his career Bolton retained his enthusiasm for natural history, and was a source of inspiration to all with whom he came in contact. His name will long be remembered as the real founder of the Bristol Museum, while his palæontological contributions will appeal to the specialist in the years to come. A clear example of the homing instinct in human nature was revealed in his expressed desire that his ashes should be scattered over the bleak Pennine hills surrounding the town of his birth and the scene of his youthful exploits among its coal fauna.

J. E. D. 